\title{
EFEKTIVITAS PELATIHAN ORS (ONLINE RESEARCH SKILLS) UNTUK MENDUKUNG STUDI DAN PENELITIAN MAHASISWA DI UIN MAULANA MALIK IBRAHIM MALANG
}

\author{
Oleh : Mufid \& Ari Zuntriana
}

\begin{abstract}
The focus of this research is to evaluate the effectiveness of Online Research Skill (ORS) training program in supporting students to study and conduct their research at UIN Maulana Malik Ibrahim Malang. The purpose is to explore how effective the ORS training in supporting their study performance. This study used research quantitative method with Kirkpatrick model approach added. Kirkpatrick Model is used to evaluate the effectiveness of ORS training program at the level of participants' reaction and participants training process. In general, the result of the study found that the training is effective, and by $86.5 \%$ have contributed to the achievement of training objectives. However, the training still needs some improvements, specifically the use of more advanced media technology for the next courses. Thus, based on those results, the researchers recommend that the LIORS curriculum need to be revised/improved based on participants' views and SCONUL curriculum.
\end{abstract}

Keywords: online research skills, information literacy, training evaluation, kirkpatrick model.

Abstrak

Fokus penelitian ini adalah untuk mengevaluasi efektivitas program pelatihan kemampuan riset online (ORS) didalam mendukung mahasiswa melakukan penelitian di UIN Maulana Malik Ibrahim Malang. Secara khusus tujuan dari penelitian ini adalah untuk mengetahui efektivitas pelatihan ORS didalam mendukung kinerja pembelajaran. Kajian ini menggunakan metode penelitian kuantitatif dengan pendekatan model Kirkpatrick. Model Kirkpatrick digunakan untuk mengevaluasi efektifitas program pelatihan ORS pada tingkat reaksi dan proses partisipasi peserta. Hasil penelitian yang ditemukan adalah program pelatihan berjalan efektif, 86,5\% responden menyatakan bahwa program pelatihan telah memberikan kontribusi didalam mendukung pencapaian tujuan pelatihan. Meskipun demikian program pelatihan ini masih memerlukan berbagai perbaikan dan peningkatan khususnya penggunaan teknologi media pada tingkat lanjut (advanced media technology) pada program-program pelatihan selanjutnya. Berdasarkan hasil temuan didalam penelitian ini, peneliti merekomendasikan kurikulum pengajaran literasi informasi tentang kemampuan riset online (LIORS) perlu ditingkatkan berdasarkan pandangan peserta dan berdasarkan kurikulum SCONUL.

Kata Kunci : efektivitas pelatihan ORS, literasi informasi, evaluasi pelatihan, model kirkpatric

\section{A. PENDAHULUAN}

Pusat Perpustakaan merupakan salah satu Arkanul Jamiah dalam penentu keberhasilan untuk mencapai cita-cita UIN Maulana Malik Ibrahim Malang. Oleh karenanya, manajemen perpustakaan berkomitmen kuat untuk mengoptimalkan fungsinya sebagai pusat sumber belajar bagi sivitas akademika.

Sejak tahun 2013, Pusat Perpustakaan menyelenggarakan program pelatihan Online
Research Skills (ORS) untuk mendukung perbaikan kualitas studi dan penelitian mahasiswa. Program ORS merupakan upaya nyata Pusat Perpustakaan dalam mendukung tercapainya 9 Program GBHU UIN Maulana Malik Ibrahim Malang menuju regional recognition and reputation (2011-2020).

Namun, selama penyelenggaraan ORS, manajemen Pusat Perpustakaan belum 
melakukan evaluasi pelatihan secara serius dalam bentuk penelitian ilmiah. Manajemen perpustakaan belum mengetahui seberapa efektif pelatihan ORS dalam membantu mahasiswa untuk meningkatkan kualitas studi dan penelitian mereka. Satu-satunya yang menjadi tolok ukur keberhasilan adalah besarnya antusiasme mahasiswa dalam mengikuti kegiatan ORS.

Di tengah-tengah banjir informasi (information overload) saat ini, kemampuan mahasiswa melakukan pencarian informasi online adalah sangat urgen. Dengan menguasai materi ORS, mahasiswa dapat menghemat sumber daya (tenaga, biaya, dan waktu) dalam menyelesaikan tugas penulisan ilmiah maupun penelitian. Diharapkan melalui pelatihan ORS mahasiswa akan cukup terbekali untuk nantinya menjadi manusia yang melek digital (digital literate) dan pembelajar seumur hidup. Kualitas SDM mahasiswa dalam bidang literasi digital dan penulisan ilmiah yang baik tentu juga akan mendukung tercapainya cita-cita besar UIN Maulana Malik Ibrahim Malang untuk meraih prestasi berupa world class university.

Penelitian mengenai efektivitas pelatihan ORS ataupun literasi informasi masih terbatas di Indonesia. Ditambah dengan realita bahwa belum banyak perpustakaan perguruan tinggi yang telah menyelenggarakan pelatihan serupa. Pendidikan pemustaka (user education) yang selama ini dijalankan oleh mayoritas perguruan tinggi di Indonesia masih hanya sebatas orientasi atau pengenalan perpustakaan (Winata \& Djunaidi, 2015).

Untuk itu, maka penelitian evaluasi ORS untuk mendukung studi dan penelitian mahasiswa di UIN Maulana Malik Ibrahim Malang menuju World Class University bertujuan:

a. Untuk mengetahui tingkat efektifitas penyelenggaraan pelatihan ORS kepada mahasiswa

b. Untuk mengetahui jenis-jenis skill literasi digital yang dibutuhkan mahasiswa

c. Untuk meningkatkan kemampuan mahasiswa dalam penguasaan skill literasi digital

d. Untuk membantu Pusat Perpustakaan dalam mendesain dan menyusun kurikulum literasi informasi dan strategi pelatihan ORS yang lebih baik di tahuntahun mendatang.

\section{B. TINJAUAN LITERATUR}

\section{1) Konsep Online Research Skills dan Literasi Informasi Digital}

Istilah online research skills sering juga disebut dengan internet/web research skills yang dapat didefinisikan sebagai kemampuan dalam melakukan temu balik informasi (information retrieval) di ranah internet. Jika ditarik ke dalam lingkup literasi informasi, maka ORS berada di bawah cakupan materi literasi digital (digital literacy) atau ada yang menyebutnya dengan istilah literasi elektronik atau $e$-literacy.

MenurutMartin (dalamKenton\&Blummer, 2010), e-literacy merupakan kesadaran, skill, pemahaman, dan pendekatan yang bersifat evaluatif-reflektif dalam melakukan tugastugas di lingkungan yang kaya informasi dan terdukung oleh TI. Sedangkan menurut Hague dan Williamson (dalam (Poore, 2014), mendefinisikan literasi digital sebagai "(kemampuan untuk) mengetahui bagaimana teknologi dan media mempengaruhi cara kita menemukan informasi, berkomunikasi dengan orang lain, dan memperoleh pengetahuan dan pemahaman." Ada tiga tingkat dalam literasi digital (Poore, 2014), yaitu: literasi digital fungsional (functional digital literacy), literasi digital jejaring (network digital literacy), dan literasi digital kritis (critical digital literacy).

Ada dua konsep berbeda yang saling berkelindan dalamliterasi digital,yaituinternet skills literacy dan internet information literacy. Literasi skill internet dimaknai sebagai seperangkat kemampuan dasar untuk mengakses/menggunakan teknologi internet, termasuk di dalamnya adalah kemampuan melakukan navigasi di lingkungan hypermedia (Kim \& Yang, 2015). Sedangkan literasi informasi internet lebih kepada kemampuan untuk memahami, menganalisa, mengevaluasi, serta menghasilkan informasi saat berada dalam situasi di mana jumlah informasi yang diperoleh sangat melimpah 
(Kim \& Yang, 2015). Dari dua definisi tersebut dapat disimpulkan bahwa literasi informasi internet merupakan kemampuan yang bersifat lanjutan dari kemampuan berinternet dasar.

Di perguruan tinggi, literasi digital sangat diperlukan karena mahasiswa, terutama tahun-tahun pertama, umumnya belum memiliki pemahaman konseptual yang memadai tentang bagaimana informasi dikelola dan bagaimana sistem mesin pencari bekerja (Brown, 2014). Sebagai pengguna aktif internet, bisa jadi mahasiswa merupakan pengguna yang handal atau memiliki tingkat literasi internet yang baik. Namun belum tentu mereka juga memiliki literasi informasi internet yang baik pula. Pengalaman seseorang dalam menggunakan internet dapat meningkatkan kemampuan literasi skillnya dalam berinternet, namun tidak pada aspek kemampuan literasi informasinya (van Deursen \& van Dijk, 2011).

Literasi informasi merupakan konsep luas yang berkembang dari istilah pelatihan penggunaanperpustakaan (libraryinstruction) atau di Indonesia sering dikenal dengan orientasi perpustakaan. Jika sebelumnya mahasiswa hanya diajarkan bagaimana cara mengakses dan menggunakan koleksi dan jasa informasi di perpustakaan, maka dalam era literasi informasi mahasiswa diajarkan bagaimana mengakses dan menggunakan informasi dalam arti yang lebih luas.

Dalam kelas literasi informasi, anak didik antara lain dibekali mengenai teknik pencarian (informasi) online, pengetahuan tentang format dokumentasi, serta pengembangan kemampuan berpikir kritis (critical thinking) pada saat mengevaluasi sebuah sumber informasi (Swanson \& Jagman, 2014). Sehingga, literasi digital bukan hanya sekadar kemampuan untuk menggunakan perangkat lunak atau mengoperasikan perangkat digital, namun juga mencakup kemampuan lain yang bersifat lebih kompleks, yaitu: kemampuan kognitif, motorik, sosiologis, dan emosi (Kenton \& Blummer, 2010).

Ada beberapa macam keahlian yang dapat dikategorikan sebagai literasi digital, di antaranya meliputi: photovisual literacy skill, reproduction literacy skill, information literacy skill, branching literacy, and socio- emotional literacy (Eshet-Alkali dan AmichaiHamburger dalam (Kenton \& Blummer, 2010). Untuk menguasai kemampuan literasi tersebut, mahasiswa perlu terlebih dulu menguasai penggunaan komputer, peramban (browser), program-program perangkat lunak, dan pangkalan data.

Mahasiswa tingkat sarjana umumnya memiliki karakteristik sebagai berikut (Asher, 2014):

a. "Mereka mulai mempelajari skill pencarian yang diperlukan untuk mengeksplorasi koleksi perpustakaan

b. Mereka membutuhkan lingkungan yang ramah pemustaka (user friendly), menawarkan bantuan dan mendorong munculnya pertanyaan

c. Mereka perlu dikenalkan dengan karakteristik ilmiah dari jasa dan koleksi perpustakaan universitas."

Karena masih berada dalam tingkat pertama dan masa awal kuliah (freshman students), mahasiswa S1 membutuhkan partisipasi aktif pustakawan dalam membantu mereka untuk membentuk kemampuan literasi informasi, tanpa harus dengan tidak menghargai pengalaman mereka berinteraksi dengan internet sebelumnya.

Dalam materi pelatihan ORS, idealnya, mahasiswa juga diajarkan bagaimana memanfaatkan informasi yang diperoleh menurut norma dan etika ilmiah yang berlaku. Dalam kelas ahli (advanced), misalnya, mahasiswa diajarkan bagaimana aturan dalam mengutip dan memparafrase secara benar. Di kelas pelatihan mahasiswa yang selama ini diselenggarakan oleh Perpustakaan UIN Maulana Malik Ibrahim Malang, pustakawan belum memberikan materi ini secara utuh karena alokasi waktu yang cukup sempit. Bentuk dari materi etika ilmiah ini sebagian telah tersampaikan seiring dengan pemberian materi praktek mengenai perangkat lunak manajemen referensi, dalam hal ini pustakawan UIN Maliki Malang menggunakan software Zotero. 


\section{2) Evaluasi Efektivitas Program Pelatihan Online Research Skills (ORS)}

Menurut (Kirkpatrick \& Kirkpatrick, 2007) efektivitas suatu program memiliki sepuluh persyaratan yaitu: melandaskan program pada kebutuhan peserta; menentukan tujuan pelatihan; menjadwalkan (pelatihan) pada waktu yang tepat; mempertimbangkan tempat; mengundang peserta yang tepat; memilih pelatih yang efektif; menggunakan metode dan alat pembelajaran yg tepat; memastikan tujuan pelatihan tercapai; memuaskan peserta; dan mengevaluasi kegiatan pelatihan.

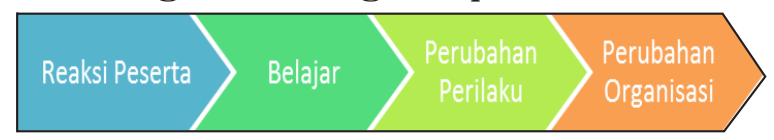

Gambar 1. Model Evaluasi Pelatihan Kirkpatrick

Dalam konteks penelitian ini, maka efektivitas program pelatihan yang dimaksud adalah tingkat keberhasilan dalam menyelenggarakan kegiatan program pelatihan ORS di Pusat Perpustakaan UIN Maulana Malik Ibrahim Malang.

\section{METODE PENELITIAN}

Penelitian ini menggunakan metode kuantitatif dengan pendekatan model Kirkpatrick. Metode Kirkpatrick ini digunakan untuk mengevaluasi efektivitas program pelatihan ORS yaitu pada tingkat reaksi peserta dan proses pelatihan peserta. Peserta pelatihan ORS adalah mahasiswa semester lima, Jurusan Teknik Informatika, Fakultas Sains dan Teknologi, UIN Maulana Malik Ibrahim Malang. Kemudian keseluruhan peserta dijadikan sampel penelitian. Jumlah peserta pelatihan sebanyak 67 Peserta yang terdiri dari 37 laki-laki dan 30 perempuan. Namun jumlah peserta yang memberikan jawaban pada pre-post test sejumlah 54 peserta. Untuk itu, data yang akan diolah dan dianalisis sebagai bahan evaluasi pelatihan ORS adalah 54 peserta yang terdiri dari 30 laki-laki dan 24 perempuan

Teknik pengumpulan data pada penelitian ini adalah :

1. Evaluasi tahapan reaksi peserta dengan menyebarkan kuesioner kepada seluruh peserta pelatihan berupa lembar evaluasi peserta

2. Evaluasi tahapan kedua berupa pre-post test, yaitu memberikan tes awal sebelum pelatihan dan tes akhir setelah pelatihan.

3. Evaluasi tahapan proses penelusuran dokumentasi untuk mendapatkan data sekunder.

Selanjutnya untuk mengetahui relevansi dan efektivitas program pelatihan ORS, peneliti mensyaratkan nilai "sangat baik" dan "baik" lebih besar atau sama dengan $80 \%$.

\section{PEMBAHASAN}

\section{1) Analisis Deskripsi Butir Soal pre- post test pelatihan ORS}

Butir-butir soal untuk menguji peserta pada pre-post test terdiri dari 15 (lima belas) butir soal. Seluruh butir tersebut digunakan untuk mengukur kemampuan pemahaman peserta sebelum dan sesudah pelatihan ORS. Berdasarkan hasil pre-test dan post-test pelatihan ORS dapat ditunjukkan pada Tabel 1. Kemampuan peserta dalam memberikan jawaban pada setiap butir soal beragam.

Tabel. 1 Hasil Pre-post test Pelatihan ORS

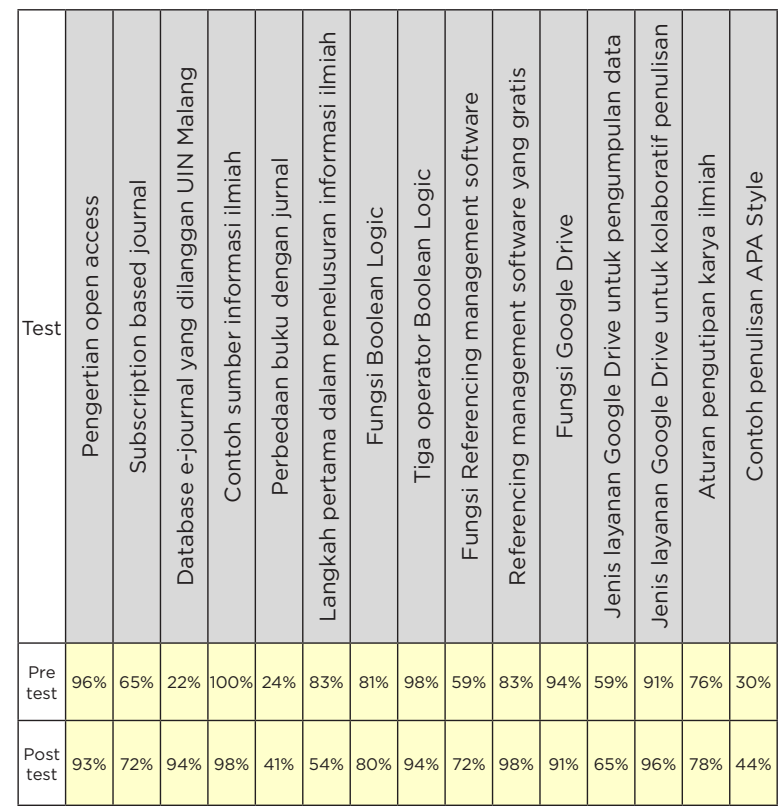

Hasil pre test pada umumnya peserta dalam memahami materi ORS sebelum pelatihan adalah sangat baik, kecuali ada beberapa butir soal 
yang sangat kurang. Di antaranya pengetahuan terhadap jurnal elektronik yang dilanggan UIN Maulana Malik Ibrahim Malang, perbedaan antara buku dan artikel jurnal, jenis gaya penulisan (referencing style) khususnya APA Style, dan fungsi aplikasi manajemen referensi (referencing management software). Namun mereka memiliki cukup pengetahuan tentang jurnal berbayar/ berlangganan (subscription based journal).

Kemudian hasil post test, secara keseluruhan peserta mengalami peningkatan pemahaman terhadap materi yang diberikan. Terdapat sembilan butir yang mengalami peningkatan persentasenya dan sebaliknya terdapat enam butir yang justru mengalami penurunan persentasenya. Hal ini menunjukkan bahwa pemahaman sebagian peserta terhadap materi yang diberikan meningkat lebih baik, namun sebagian yang lain, justru pemahaman peserta mengalami penurunan.

Berdasarkan pada hasil pre-post test di atas, kemudian dilakukan analisis dengan uji t untuk melihat ada dan tidaknya perubahan/ peningkatan pengetahuan peserta setelah mengikuti pelatihan ORS. Hasil analisis statistik ditunjukkan pada Diagram di bawah ini.

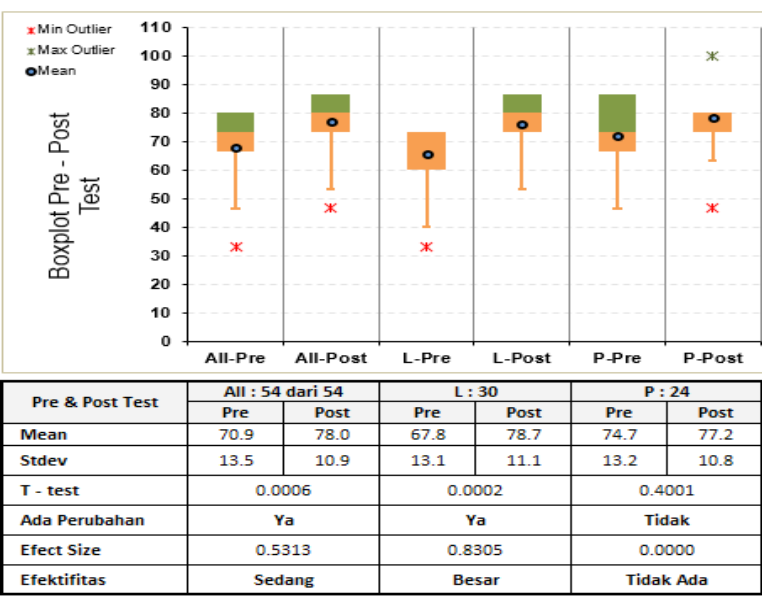

Diagram Hasil Uji t Terhadap Hasil Pre-post test Pelatihan ORS

Berdasarkan olah data statistik dapat diketahui bahwa rata-rata nilai pre-test dan post-test menunjukkan perubahan positif. Nilai rata-rata post-test lebih tinggi (78.0) daripada nilai rata-rata pre-test (70.9). Pengetahuan awal sebelum dilakukan pelatihan, peserta perempuan lebih tinggi (74.7) daripada pengetahuan peserta laki-laki (67.8), namun setelah dilakukan pelatihan, peserta laki-laki mengalami peningkatan lebih baik (78.7) daripada peserta perempuan (77.2). Pengetahuan peserta secara umum meningkat sebesar $7 \%$, pesertalaki-laki $11 \%$ dan perempuan hanya $3 \%$ mengalami peningkatan pengetahuannya setelah mengikuti pelatihan. Secara keseluruhan peserta mengalami perubahan pada tingkat sedang 53\% (0.5313), namun jika dilihat dari jenis kelamin, maka hanya peserta laki-laki yang mengalami perubahan pengetahuan setelah mengikuti pelatihan sebesar $83 \%$ (0.8305), dan peserta perempuan tidak mengalami perubahan sama sekali (0.0000).

Secara umum jika ditinjau dari hasil prepost test, tingkat efektivitas kegiatan pelatihan ORS sangat efektif bagi peserta laki-laki yang memberikan dampak perubahan sebesar $83 \%$, dan sebaliknya tidak efektif bagi peserta perempuan karena dampak pelatihan bagi perempuan sebesar $0 \%$. Namun, secara keseluruhan pelatihan ORS berlangsung pada tingkatan efektivitas "sedang" yaitu sebesar 53\% .

\section{2) Analisis Deskripsi Butir Soal Eval- uasi Reaksi Peserta}

Butir-butir soal yang dijadikan instrumen untuk mengetahui reaksi peserta setelah mengikuti pelatihan ORS dibagi menjadi dua pendekatan yaitu pendekatan secara kuantitatif dan pendekatan secara kualitatif. Butir-butir soal untuk analisis kuantitatif terdiri dari sepuluh butir pertanyaan yang terbagi dalam dua aspek yaitu tiga butir pertanyaan merupakan aspek untuk melihat tingkat relevansi yaitu (butir 1,2, dan 10), dan tujuh butir untuk mengetahui tingkat efektivitas pelatihan (butir 3,4,5,6,7,8,9). Hasil reaksi peserta ditunjukkan pada Tabel 2 .

Tabel 2. Instrumen Kuantitatif Evaluasi Reaksi Peserta Terhadap Pelatihan ORS

\begin{tabular}{|l|c|c|c|c|c|c|}
\hline \multirow{3}{*}{\multicolumn{1}{|c}{ Pertanyaan }} & A & B & C & D & E & \multirow{2}{*}{ Total } \\
\cline { 2 - 7 } & Sb & Baik & Cukup & Kurang & SK & \\
\hline Pengetahuan Peserta & 4 & 36 & 10 & 4 & 0 & 54 \\
\hline Kualitas Materi & 8 & 39 & 7 & 0 & 0 & 54 \\
\hline Fasilitas belajar & 16 & 34 & 3 & 0 & 1 & 54 \\
\hline $\begin{array}{l}\text { Pemahaman Tujuan } \\
\text { Pelatihan }\end{array}$ & 15 & 30 & 8 & 1 & 0 & 54 \\
\hline Efektivitas metode & 6 & 30 & 15 & 2 & 1 & 54 \\
\hline Modul pelatihan & 19 & 30 & 5 & 0 & 0 & 54 \\
\hline Waktu pelatihan & 19 & 30 & 5 & 0 & 0 & 54 \\
\hline Susunan materi & 19 & 30 & 5 & 0 & 0 & 54 \\
\hline Pelatih menguasai materi & 19 & 30 & 5 & 0 & 0 & 54 \\
\hline $\begin{array}{l}\text { Peningkatan pemahaman } \\
\text { peserta }\end{array}$ & 19 & 30 & 5 & 0 & 0 & 54 \\
\hline \multicolumn{1}{|c}{ (\%) } & $\mathbf{2 6 . 7 \%}$ & $\mathbf{5 9 . 1 \%}$ & $\mathbf{1 2 . 6 \%}$ & $\mathbf{1 . 3 \%}$ & $\mathbf{0 . 4 \%}$ & $\mathbf{1 0 0 \%}$ \\
\hline
\end{tabular}


Berdasarkan Tabel 2 di atas, maka secara umum reaksi peserta setelah mengikuti pelatihan ORS sangat positif, yaitu peserta memberikan penilaian terhadap pelatihan ORS sangat baik sebesar $26.7 \%$, baik sebesar $59.1 \%$, dan cukup sebesar $12.6 \%$. Namun demikian masih ada peserta yang memberikan penilaian sangat kurang sebesar $0.4 \%$.

Tabel 3 Persentase Jumlah jawaban Instrumen Kuantitatif berdasar relevansi dan Efektifitas pelatihan ORS

\begin{tabular}{|c|c|c|c|c|c|}
\hline Kelompok & Pertanyaan & $\begin{array}{c}\text { \% Sangat } \\
\text { Baik } \\
\text { dan Baik }\end{array}$ & $\%$ Cukup & $\begin{array}{c}\% \\
\text { Kurang }\end{array}$ & $\begin{array}{c}\% \text { Sangat } \\
\text { Kurang }\end{array}$ \\
\hline Relevan* $\mathbf{V}$ & $1,2 \& 10$ & $84.0 \%$ & $13.6 \%$ & $2.5 \%$ & $0.0 \%$ \\
\hline Efektif* $\quad \boldsymbol{V}$ & $3,4,5,6,7,8,9$ & $86.5 \%$ & $12.2 \%$ & $0.8 \%$ & $0.5 \%$ \\
\hline
\end{tabular}

Selanjutnya, jika dilihat dari tingkat relevansi dan efektivitas pelatihan ORS sebagaimana yang ditunjukkan pada Tabel 3, maka menurut peserta bahwa tingkat relevan pelatihan sebesar $84.0 \%$ dan tingkat efektivitas pelatihan sebesar $86.5 \%$. Hal ini berarti bahwa pelatihan telah memenuhi standar relevansi dan standar efektivitas karena standar efektivitas dan relevansi pelatihan minimal sebesar $80 \%$. Besarnya relevansi dan efektivitas pelatihan berdampak pada besarnya kontribusi pada tercapainya tujuan.

Kemudian secara kualitatif bertujuan untuk mendapatkan gambaran tentang harapan dan masukan peserta terhadap pelatihan ORS. Evaluasi reaksi peserta dari aspek harapan mereka terhadap keberlangsungan pelatihan ORS diberikan lima butir pertanyaan. Hasil dari jawaban mereka terhadap lima butir pertanyaan sangat beragam seperti ditunjukkan pada Tabel 4.
Tabel 4

Jawaban Kualitatif Reaksi Peserta Setelah Mengikuti Pelatihan ORS

\begin{tabular}{|c|c|c|}
\hline $\begin{array}{l}\text { Butir Per- } \\
\text { tanyaan }\end{array}$ & Reaksi Peserta & Jumlah \\
\hline \multirow{4}{*}{$\begin{array}{l}\text { 1. Apa yang } \\
\text { anda } \\
\text { sukai dari } \\
\text { pelatihan } \\
\text { ini? }\end{array}$} & Metode & 9 \\
\hline & Materi & 3 \\
\hline & Praktek & 4 \\
\hline & Akomodasi & 4 \\
\hline \multirow{8}{*}{$\begin{array}{l}\text { 5. Peruba- } \\
\text { han apa } \\
\text { yang } \\
\text { diperlu- } \\
\text { kan dalam } \\
\text { pelatihan } \\
\text { ini agar } \\
\text { menja- } \\
\text { di lebih } \\
\text { baik? }\end{array}$} & Workshop & 1 \\
\hline & Materi diperkaya & 8 \\
\hline & $\begin{array}{l}\text { Fasilitas pelatihan } \\
\text { ditingkatkan }\end{array}$ & 7 \\
\hline & $\begin{array}{l}\text { Penguasaan materi } \\
\text { pelatih perlu diting- } \\
\text { katkan }\end{array}$ & 2 \\
\hline & Metode diperbaiki & 10 \\
\hline & Praktek diperbanyak & 2 \\
\hline & $\begin{array}{l}\text { Sosialisasi ditingkat- } \\
\text { kan }\end{array}$ & 1 \\
\hline & $\begin{array}{l}\text { Waktu pelatihan } \\
\text { diperpanjang }\end{array}$ & 3 \\
\hline \multirow{3}{*}{$\begin{array}{l}\text { 13. Apa yang } \\
\text { anda } \\
\text { lakukan } \\
\text { setelah } \\
\text { mengikuti } \\
\text { pelatihan } \\
\text { ini? }\end{array}$} & $\begin{array}{l}\text { Menerapkan materi } \\
\text { pelatihan }\end{array}$ & 36 \\
\hline & $\begin{array}{l}\text { Mencari sumber-sum- } \\
\text { ber lain yang terkait } \\
\text { dengan materi }\end{array}$ & 6 \\
\hline & $\begin{array}{l}\text { Menyebarkan ilmu dan } \\
\text { materi kepada orang } \\
\text { lain }\end{array}$ & 1 \\
\hline \multirow{2}{*}{$\begin{array}{l}\text { 16. Apa- } \\
\text { kah ada } \\
\text { kesulitan } \\
\text { dalam } \\
\text { mengikuti } \\
\text { pelatihan } \\
\text { ini? }\end{array}$} & Ya & 17 \\
\hline & Tidak & 26 \\
\hline \multirow{4}{*}{$\begin{array}{l}\text { 18. Apakah } \\
\text { anda } \\
\text { memiliki } \\
\text { pendapat } \\
\text { lain? }\end{array}$} & $\begin{array}{l}\text { Sosialisasi diperlukan/ } \\
\text { tindak lanjut }\end{array}$ & 1 \\
\hline & $\begin{array}{l}\text { Waktu dan metode } \\
\text { pelatihan }\end{array}$ & 7 \\
\hline & Materi diperluas & 3 \\
\hline & Sudah cukup & 1 \\
\hline
\end{tabular}

Hasil reaksi peserta dapat dijelaskan sebagai berikut:

1) Peserta menyukai pelatihan ORS dari aspek metode, materi, praktek dan akomodasi 
yang disedikan oleh panitia. Aspek metode adalah yang paling disukai oleh peserta.

2) Peserta menginginkan perubahan pelatihan ORS ke arah lebih baik dengan cara antara lain, tindak lanjut pengembangan materi, metode dan waktu pelatihan; fasilitas belajar seperti, LCD proyektor, video tutorial; sosialisasi pelatihan; dan penguasaan materi pelatih. Aspek yang paling diinginkan agar ditindaklanjuti adalah metode dan kedalaman materi pelatihan.

3) Setelah pelatihan, peserta berkeinginan / berencana untuk menerapkan materi pelatihan; mencari sumber lain terkait dengan materi; menyebarkan ilmu / sharing pengetahuan kepada orang lain. Aspek yang paling banyak akan direncanakan peserta setelah pelatihan adalah menerapkan materi yang diajarkan.

4) Sebagian peserta dalam mengikuti pelatihan masih mengalami kesulitan.

5) Sebagian besar peserta berpendapat bahwa pelatihan perlu disosialisasikan; materi, metode dan waktu perlu dikaji ulang;

\section{3) Tingkat Efektifitas Penyeleng- garaan Pelatihan ORS di Pusat Perpustakaan UIN Maulana Malik Ibrahim Malang}

Efektivitas dan relevansi merupakan kunci keberhasilan dalam mencapai tujuan suatu pelatihan. Besar kecilnya perubahan yang dihasilkan oleh suatu pelatihan menunjukkan besar kecilnya kontribusi pada pencapaian tujuan. Oleh karena itu, semakin besar kontribusi terhadap pencapaian tujuan maka semakin efektif suatu pelatihan (Mahmudi, 2005)

Berdasarkan olah data statistik pada prepost test di atas, secara umum pelatihan ORS memberikan perubahan positif yaitu materi yang diberikan dalam pelatihan tersebut mampu meningkatkan pemahaman dan ketrampilan peserta. Sementara tingkat efektivitas kegiatan pelatihan ORS berjalan sangat efektif bagi peserta laki-laki, dan sebaliknya tidak efektif bagi peserta perempuan. Namun, secara keseluruhan pelatihan ORS berlangsung pada tingkatan efektivitas "sedang".

Pelatihan ORS selama ini yang diselenggarakan oleh Pusat Perpustakaan UIN Maulana Malik Ibrahim Malang masih belum memberikan dampak positif bagi peserta perempuan dan hanya berdampak positif bagi peserta laki-laki. Berdasarkan nilai post-test peserta perempuan, hampir $50 \%$ dari mereka nilainya tidak mengalami peningkatan, sebagian justru menurun.

Hasil evaluasi reaksi peserta menggambarkan bahwa aspek metode, materi, praktek dan akomodasi yang disediakan oleh panitia merupakan aspek yang paling disukai oleh peserta. Namun sebagian peserta masih mengalami kesulitan untuk mengikuti pelatihan. Oleh karena itu, sebagian besar peserta berpendapat bahwa seharusnya waktu sosialisasi perlu ditambah dan perlunya mengkaji ulang materi, metode dan waktu pelaksanaan pelatihan.

Sementara rencana ingin dilakukan atau tindaklanjut peserta setelah pelatihan adalah adanya keinginan peserta untuk menerapkan materi pelatihan; mencari sumber lain terkait dengan materi; menyebarkan ilmu/sharing pengetahuan kepada orang lain. Aspek yang paling banyak akan direncanakan peserta setelah pelatihan adalah menerapkan materi yang diajarkan untuk menyelesaikan studi dan penelitian mereka.

\section{4) Jenis-Jenis Pengetahuan dan Skill Literasi Digital yang Dibutuhkan Mahasiswa UIN Maulana Malik Ibrahim Malang}

Berdasarkan pada Tabel 1, menunjukkan bahwa jenis-jenis pengetahuan dan skill/ keterampilan literasi digital yang dibutuhkan dalam mendukung studi dan penelitian mahasiswa UIN Maulana Malik Ibrahim Malang adalah pengenalan dan praktek pemanfaatan sumber-sumber informasi online, khususnya database yang dilanggan oleh UIN Maulana Malik Ibrahim Malang, yaitu Proquest, Emerald dan Springer. Pengenalan dan praktek pemanfaatan RMS untuk pengorganisasian informasi ilmiah online (e-resources) berupa artikel e-journal, ebook, dan sumber-sumber informasi online 
lainnya. Pengenalan dan praktek modelmodel pengutipan dan penulisan daftar referensi (referencing styles) yang sangat penting dalam penulisan karya ilmiah atau karya penelitian. Model yang perlu dikenalkan dan dipraktekkan adalah Chicago Style, APA Style, dan MLA Style. Pengenalan dan praktek sarana kolaboratif online khususnya Google Drive sebagai sarana kolaboratif meliputi Google Form, Google Doc, dan Google Slides untuk presentasi.

\section{5) Peningkatan Kemampuan Ma- hasiswa dalam Penguasaan Skill Literasi Digital}

Berdasarkan analisis reaksi peserta di atas, aspek yang paling diinginkan peserta dalam upaya perbaikan adalah melakukan perbaikan aspek metode penyampaian materi oleh pelatih dan kedalaman materi pelatihan. Oleh karena itu, pihak perpustakaan perlu melakukan perbaikan-perbaikan, antara lain:

a. Pengembangan materi pelatihan,

b. Mengevaluasi metode pelatihan yang diterapkan

c. Menambah waktu pelatihan

d. Menyediakan fasilitas belajar seperti, LCD proyektor, video tutorial;

e. Meningkatkan dan memperpanjang durasi kegiatan sosialisasi pelatihan kepada mahasiswa

f. Penguasaan materi pelatih perlu ditingkatkan

\section{6) Desain Kurikulum Literasi Infor- masi dan Strategi Pelatihan ORS Berdasarkan Masukan Peserta.}

Berdasarkan hasil analisis efektifitas pelatihan ORS di atas, maka kurikulum literasi informasi untuk ORS diperlukan revisi/perbaikan. Konstruksi kurikulum dikembangkan berdasarkan draft kurikulum literasi informasi PTKIN. Draft kurikulum ini mengacu pada kurikulum SCONUL yaitu kurikulum yang berlandaskan pada 7 pilar. Berdasarkan revisi kurikulum di atas, maka modul pelatihan juga akan direvisi, baik dari sisi materi, metode dan waktu.

Strategi yang telah diterapkan pada setiap pelatihan ORS selama ini belum berjalan dengan maksimal. berdasarkan masukan dari peserta pelatihan, maka re-desain strategi pelatihan ORS perlu dilakukan agar pelatihan mampu mendukung lebih baik lagi dalam mencapai tujuan. Rencana perbaikan strategi di antaranya adalah:

1) Sosialisasi pelatihan melalui berbagai media dengan waktu yang mencukupi

2) Menerapkan manajemen waktu dengan lebih baik

3) Penambahan waktu sesuai dengan kebutuhan modul pelatihan yang terbagi dalam dua sesi (pagi dan siang)

4) Penyediaan teknologi media pelatihan yang lebih representatif

5) Metode penyampaian materi menggunakan pendekatan partisipasi peserta

Dari uraian hasil evaluasi pelatihan ORS di atas, menunjukkan bahwa pelatihan ORS sudah berjalan dengan efektif, dan materi yang diberikan relevan dengan kebutuhan. Hal ini berarti penyelenggaraan pelatihan ORS selama ini telah memberikan kontribusi nyata dalam mendukung studi dan penelitian mahasiswa UIN Maulana Malik Ibrahim Malang. Namun demikian, masih ditemukan beberapa kendala yang menghambat peserta untuk mengikuti pelatihan diperlukan upaya perbaikan untuk lebih optimal dalam mencapai tujuan pelatihan.

Berdasarkan temuan penelitian tersebut, maka dapat disebut juga bahwa hasil pelatihan ini berkontribusi riil dalam mendukung studi dan penelitian mahasiswa. Dalam jangka panjang, jika hasil evaluasi ini diterapkan dalam pelatihan-pelatihan ORS (Online Research Skills) di masa mendatang maka ini tentu akan berdampak sangat positif dalam upaya penguatan skills mahasiswa dan perbaikan mutu karya ilmiah yang dihasilkan. Hal ini tentu akan mendukung dan mengakselerasi proses tercapainya tujuan Universitas berupa World Class University.

\section{KESIMPULAN}

1. Tingkat efektivitas pelatihan ORS bagi mahasiswa UIN Maulana Malik Ibrahim telah berjalan secara efektif sebesar $84.0 \%$ dan relevansi materi yang disampaikan sebesar $86.5 \%$. Hal ini berarti hasil pelatihan berkontribusi terhadap pencapaian tujuan 
ORS. Namun, tingkat efektivitas yang sudah dicapai masih perlu ditingkatkan khususnya penyiapan teknologi media pelatihan yang lebih representatif.

2. Jenis-jenis pengetahuan dan skill/ ketrampilan literasi digital yang dibutuhkan dalam mendukung studi dan penelitian mahasiswa UIN Maulana Malik Ibrahim Malang adalah pengetahuan dan skill tentang sumber-sumber informasi online, pengorganisasian informasi ilmiah online, referencing styles dan sarana kolaboratif.

3. Upaya peningkatan kemampuan mahasiswa dalam penguasaan skill literasi digital melalui pendekatan berupa: pengembangan materi pelatihan, memperbaiki metode pelatih dalam menyampaikan materi, penambahan waktu pelatihan, menyediakan teknologi media pelatihan yang lebih representatif, dan memberikan alokasi waktu yang cukup untuk sosialiasi kegiatan.

4. Kurikulum LI-ORS perlu direvisi/ diperbaiki. Desain konstruksi kurikulum dikembangkan berdasarkan draft kurikulum literasi informasi PTKIN. Draft kurikulum ini mengacu pada kurikulum SCONUL yaitu kurikulum yang berlandaskan pada 7 pilar.

\section{DAFTAR PUSTAKA}

Asher, A. D. (2014). Search epistemology: teaching students about information discovery. In Not just where to click: teaching students how to think about information. Chicago: Association of College \& Research Libraries.

Brown, P. (2014). Studying sources: truth, method, and teaching bibliography. In Not just where to click: teaching students how to think about information (pp. 139-154). Chicago: Association of College \& Research Libraries.

Kenton, J., \& Blummer, B. (2010). Promoting Digital Literacy Skills: Examples from the Literature and Implications for Academic Librarians. Community \& Junior College Libraries, 16(2), 84-99. http://doi. org $/ 10.1080 / 02763911003688737$

Kim, E., \& Yang, S. (2015). Internet literacy and digital natives' civic engagement: Internet skill literacy or Internet information literacy? Journal of Youth Studies, 1-19. http:// doi.org/10.1080/13676261.2015.1083961

Kirkpatrick, D. L., \& Kirkpatrick, J. D. (2007). Implementing The Four Levels: A Practical Guide for Effective Evaluation of Training Program.

Mahmudi. (2005). Manajemen Kinerja Sektor Publik (1st ed.). Yogyakarta: UPP AMP YKPN.

Poore, M. (2014). Studying and researching with social media. Thousand Oaks, CA: SAGE Publications.

Swanson, T. A., \& Jagman, H. (Eds.). (2014). Not just where to click: teaching students how to think about information. Chicago: Association of College and Research Libraries, a division of the American Library Association.

van Deursen, A., \& van Dijk, J. (2011). Internet skills and the digital divide. New Media \& Society, 13(6), 893-911. http://doi. org/10.1177/1461444810386774

Winata, A. P., \& Djunaidi, A. (2015). Efektifitas Pelatihan Literasi Informasi. Universitas Gadjah Mada, Yogyakarta. 